\title{
Cotranslational folding of a pentarepeat
}

\section{$\beta$-helix protein}

Luigi Notari ${ }^{1 \#}$, Markel Martínez-Carranza ${ }^{1 \#}$, Jose Arcadio Farias-Rico ${ }^{1 \#,}$

Pål Stenmark ${ }^{*}$, Gunnar von Heijne, ${ }^{1,2 *}$

${ }^{1}$ Department of Biochemistry and Biophysics

Stockholm University, SE-106 91 Stockholm, Sweden

${ }^{2}$ Science for Life Laboratory Stockholm University, Box 1031, SE-171 21 Solna, Sweden

*Corresponding authors. GvH Phone: Int+46-8-16 25 90, E-mail: gunnar@,dbb.su.se.

PS Phone: Int+46-8-16 37 29, E-mail: stenmark@dbb.su.se.

\# These authors contributed equally to this work.

Keywords: pentapeptide-repeat protein; beta-helix; cotranslational folding; X-ray structure; Clostridium botulinum 


\begin{abstract}
It is becoming increasingly clear that many proteins start to fold cotranslationally, before the entire polypeptide chain has been synthesized on the ribosome. One class of proteins that a priori would seem particularly prone to cotranslational folding is repeat proteins, i.e., proteins that are built from an array of nearly identical sequence repeats. However, while the folding of repeat proteins has been studied extensively in vitro with purified proteins, only a handful of studies have addressed the issue of cotranslational folding of repeat proteins. Here, we have determined the structure and studied the cotranslational folding of a $\beta$-helix pentarepeat protein from the human pathogen Clostridium botulinum - a homolog of the Fluoroquinolone Resistance Protein MfpA - using an assay in which the SecM translational arrest peptide serves as a force sensor to detect folding events. We find that cotranslational folding of a segment corresponding to the first four of the eight $\beta$-helix coils in the protein produces enough force to release ribosome stalling, and that folding starts when this unit is $\sim 35$ residues away from the P-site, near the distal end of the ribosome exit tunnel. An additional folding transition is seen when the whole PENT moiety emerges from the exit tunnel. The early cotranslational formation of a folded unit may be important to avoid misfolding events in vivo, and may reflect the minimal size of a stable $\beta$-helix since it is structurally homologous to the smallest known $\beta$-helix protein, a four-coil protein that is stable in solution.
\end{abstract}




\section{Introduction}

With their simple, repetitive architecture composed of a linear array of nearly identical folding units, repeat proteins represent an important paradigm for protein folding studies [1]. Typical repeat proteins are ankyrin repeat proteins, tetratricorepeat proteins, HEAT repeat proteins, leucine-rich repeat proteins, and various kinds of $\beta$ helix proteins [2]. In general, the folding of an individual repeat is thermodynamically unfavorable while the interaction between successive repeats is favorable, meaning that a critical number of folded neighboring repeats need to interact in order for the folded state to become more stable than the unfolded state [1]. From an evolutionary point of view it is believed that complex repeat proteins originated by duplication and fusion of smaller identical segments, adding recurrent favorable interactions [3-5].

As for protein folding studies in general, folding of repeat proteins has mainly been analyzed in vitro using purified proteins; $[6,7]$. In vivo, however, proteins can start to fold cotranslationally [8]. For repeat proteins in particular, cotranslational folding, where repeats are added to a growing folding nucleus as they emerge from the ribosome exit tunnel, seems a likely scenario. Still, only a handful of studies have addressed the issue of cotranslational folding of repeat proteins $[9,10]$.

The pentapeptide repeat protein (PRP) family belongs to the class of $\beta$-helix proteins. In PRPs, four pentapeptide repeats form an approximately square repeating unit (a "coil"), and a string of coils form the $\beta$-helix [11]. The hydrophobic core inside the $\beta$ helix contains conserved Phe and Leu residues, while polar and charged residues decorate its surface, in many cases mimicking a DNA double helix [12]. Here, we analyze the cotranslational folding of a PRP from Clostridium botulinum (PENT), a 217-residue polypeptide that forms a highly regular eight-coil $\beta$-helix, homologous to 
the Fluoroquinolone Resistance Protein MfpA from Mycobacterium tuberculosis [12, 13]. Using a force-sensing assay based on the SecM translational arrest peptide (AP) [14], we find that an early folding transition takes place when approximately four Nterminal coils have emerged from the ribosome exit tunnel, i.e., when only about half the protein has been synthesized; notably, a homologous four-coil PRP from Nostoc punctiforme [15] is stable in solution. A second folding transition is seen when the entire PENT domain emerges from the exit tunnel. Since incompletely folded $\beta$-helix proteins are prone to aggregation [7], the early cotranslational formation of a folded four-coil unit may be important to avoid misfolding events in vivo, and may reflect the minimal size of a stable $\beta$-helix.

\section{Results}

PENT forms a highly regular $\beta$-helix

To provide a structural context for our cotranslational folding studies, we first determined the crystal structure of the Clostridium botulinum pentapeptide repeatcontaining protein PENT (UniProtKB A0A0M0A2X5; see Supplementary Table 1 for refinement statistics and Supplementary Fig. S1 for B-values). PENT crystallizes as a dimer and adopts a right-handed quadrilateral $\beta$-helix fold, Fig. 1a, first observed in the M. tuberculosis MfpA PRP [13]. Four parallel $\beta$-sheets constitute the sides of the square-shaped helix, and its diameter varies between 20 to $30 \AA$ through the squared shape of every coil. The parallel nature of the $\beta$-sheets gives a left-handed helicity to the $\beta$-helix, each coil being slightly offset from the previous one. The $\mathrm{N}$ - and $\mathrm{C}$ terminal caps adopt an $\alpha$-helical fold that is perpendicular to the axis of the $\beta$-helix, and seal off its hydrophobic core. A dimer interface is formed between the C-terminal 
caps of two PENT monomers, with the $\alpha$-helices oriented perpendicularly to each other. The two monomers are coaxial, forming a $100 \AA$ long dimer.

Each $\beta$-helix coil is formed by four pentapeptide repeat units. The central residue of each unit is most often a phenylalanine, and occasionally a methionine, Fig. 1b. These core residues are designated with the $i$ position in the repeat, and their side chains point inwards in the $\beta$-helix. Residues in the $i^{-2}$ position also point inwards and constitute the corners of the quadrilateral $\beta$-helix. Cysteine and serine residues populate this position most often. The side chains of residues in position $i^{-1}, i^{+1}$ and $i^{+2}$ point outwards, and are often populated by amino acids with charged side chains [11, 12]. It is worth noting that no disulfide bonds are formed between any cysteine residues, which might otherwise slow down the folding process. No proline residues are found in the coils, which could otherwise also slow down folding.

\section{Force-profile analysis of cotranslational folding}

Translational arrest peptides (APs) are short stretches of polypeptide that interact with the ribosome exit tunnel in such a way that translation is stalled when the ribosome reaches the last codon in the AP [16]. The stall can be overcome by external forces pulling on the nascent chain [17], and the stalling efficiency of a given AP is reduced in proportion to the magnitude of the external pulling force $[18,19]$. APs can therefore be used as force sensors to follow a range of cotranslational processes such as membrane protein biogenesis [18, 20], protein translocation [21], and protein folding [14, 22-27].

A schematic representation of how cotranslational protein folding generates force on the AP is shown in Fig. 2a. For short constructs for which there is not enough room in the ribosome exit tunnel for the protein to fold at the point when the ribosome reaches 
the end of the AP, or for long constructs where the protein has already folded when the ribosome reaches the end of the AP, little force is generated and translation is efficiently stalled. However, for constructs of intermediate length where there is just enough space in the tunnel for the protein to fold if the tether is stretched out from its equilibrium length, some of the free energy gained upon folding will be stored as elastic energy (increased tension) in the nascent chain, reducing stalling. By measuring the stalling efficiency for a series of constructs of increasing length, a force profile can be generated that shows how the folding force varies with the location of the protein in the exit tunnel [14], and hence when during translation the protein starts to fold. The approach has been validated in a number of ways. It has been shown that the main peak in a force profile correlates with the acquisition of thermolysin resistance of the folding protein in an on-ribosome pulse-proteolysis assay [26], and with the appearance of folded protein in the exit tunnel as visualized by cryo-EM [14, 22, 24]. Further, the amplitude of the peak correlates with the thermodynamic stability of the folded protein [26]. Finally, force profiles can be quantitatively reproduced by molecular dynamics simulations of cotranslational protein folding [14, 24], and are affected by changes in the size and shape of the exit tunnel in ways expected for cotranslational folding [25].

The basic construct used in the force-measurement experiment is shown in Fig. $2 \mathrm{~b}$. The C-terminal end of the force-generating moiety (PENT in the present case) is connected via a variable-length linker to the E. coli SecM AP [28], which in turn is followed by a 23-residue C-terminal tail (included to allow separation of arrested and full-length forms of the protein by SDS-PAGE). Shorter constructs (up to $L=216$ residues) also carry a 154-residue segment of the E.coli LepB protein at the N terminus, in order to make the protein run in a convenient region of the SDS-PAGE 
gel. Constructs are translated for $20 \mathrm{~min}$. in the PURExpress ${ }^{\mathrm{TM}}$ coupled in vitro transcription-translation system [29] in the presence of $\left[{ }^{35} \mathrm{~S}\right]-$ Met, the radiolabeled protein products are analyzed by SDS-PAGE, and bands are quantitated on a phosphoimager, Fig. 2c. For constructs where little pulling force is exerted on the AP, stalling is efficient and the arrested (A) form of the protein dominates. In contrast, for constructs experiencing a high pulling force there is little stalling and the full-length (FL) form dominates. We use the fraction full-length protein, $f_{F L}=I_{F L} /\left(I_{F L}+I_{A}\right)$ (where $I_{i}$ is the intensity of band $\left.i=\mathrm{A}, \mathrm{FL}\right)$, as a measure of the force exerted on the AP [18]. PENT force profile

To generate the full force profile for PENT, a series of PENT constructs where first the linker and then the PENT-moiety were progressively truncated from the Cterminal end (see Supplementary Table 2 for sequences of all constructs) were translated in the PURE system, and $f_{F L}$ was plotted as a function of the length $L$ of the PENT + linker + AP part, Fig. 3. The force profile has two minor peaks at $L \approx 70$ and $L \approx 115$ residues (corresponding, respectively, to PENT truncations at residues $\sim 50$ and $\sim 95$ ), and two major, $\sim 20$-residue wide peaks at $L \approx 145-165$ and $L \approx 245-265$ residues (corresponding, respectively, to PENT truncations at residues $\sim 125-145$ and to full-length PENT attached to the ribosomal P-site via a $~ 30-50$-residue C-terminal linker). The latter is at similar tether lengths as seen before for proteins folding in the exit port region of the ribosome tunnel [24, 26], and therefore very likely represents folding of full-length PENT into its native state.

\section{Effects of mutations in the hydrophobic core of PENT}

To ascertain whether the early peaks in the force profile reflect partial folding of the PENT $\beta$-helix or may be caused by, e.g., minor alterations in the way the nascent 
chain interacts with the ribosome exit tunnel, we mutated hydrophobic core residues in relevant $\beta$-helix coils in the $[L=114]$ and $[L=150]$ constructs, Fig. 4a. Simultaneous mutation of four core residues in the N-terminal cap and coils 2-3 to Ala (V15A, F18A, F57A, F67A) in the $[L=114]$ construct had no significant effect on $f_{F L}$ (the $f_{F L}$ value changed from 0.38 to 0.44 , data not shown), meaning that peak II most likely does not represent a partially folded intermediate. Peak I is also narrow and of even lower amplitude, and hence is equally unlikely to represent a major folding event. In contrast, mutations in core residues of the $[L=150]$ construct had strong, cumulative effects on $f_{F L}$. The double mutation $\mathrm{V} 15 \mathrm{~A}+\mathrm{F} 18 \mathrm{~A}$ in the $\mathrm{N}$-terminal cap domain led to a significant decrease in $f_{F L}$ when compared to the wildtype sequence, Fig. $4 \mathrm{~b}$, suggesting that the cap plays an important role in the folding process and stabilizes the folding intermediate [30]. The introduction of multiple $\mathrm{F} \rightarrow \mathrm{A}$ mutations within the $\beta$-helix coils (F47A, F57A, F67A, F97A) also led to strong reductions in $f_{F L}$, Fig. 4c.

To determine the role of each individual $\beta$-helix coil, we introduced paired $\mathrm{F} \rightarrow \mathrm{A}$ mutations in the hydrophobic core of the $[L=150]$ construct, starting in the $\mathrm{N}$-terminal coil and moving progressively towards the C-terminal coil. Paired mutations closer to the C-terminal end of the $[L=150]$ construct had stronger effects on $f_{F L}$, Fig. $4 \mathrm{~d}$, except when placed in the fifth coil (F122A+F127A), where they had no effect. Thus, the fifth coil is not part of the $\beta$-helix formed in the $[L=150]$ construct, presumably because it remains buried within the exit tunnel.

Finally, to better determine the end of the folded $\beta$-helix in the $[L=150]$ construct, starting from the C-terminal end of the PENT part (at PENT residue 129) we replaced five amino acids at a time with alternating Gly and Ser residues. Replacement of up to 
20 residues had little effect on $f_{F L}$, but when the C-terminal 25 residues were replaced there was a strong drop in $f_{F L}$, similar to the one seen for the F87A+F97A double mutant, Fig. 5. Thus, the C-terminal end of the folded $\beta$-helix in the $[L=150]$ construct is located between PENT residues 104 and 109.

As a control to ascertain that $\mathrm{F} \rightarrow \mathrm{A}$ mutations destabilize full-length PENT, we performed a pulse-proteolysis assay [31] on a [L=238/SecM(stop)] construct, which contains full-length PENT and has a stop codon placed at the end of the SecM AP (Supplementary Fig. S2). Construct were expressed in the PURExpress ${ }^{\mathrm{TM}}$ in vitro translation system and subjected to pulse-proteolysis by thermolysin. The $[L=238 / \operatorname{SecM}($ stop) $]$ construct is fully resistant to thermolysin treatment (average fraction resistant $=0.99)$. In contrast, $[L=238 \mathrm{~F} 87 \mathrm{~A} / \mathrm{SecM}($ stop) $]$ and $[L=238$ F87A+F97A/SecM(stop)] constructs are partially degraded by thermolysin (average fraction resistant $=0.46$ and 0.51 , respectively). $\mathrm{F} \rightarrow \mathrm{A}$ mutations thus both destabilize full-length PENT and perturb the folding of the $[L=150]$ construct.

We conclude that the $[L=150]$ construct contains a folded $\beta$-helix domain that extends from the N-terminal cap to the fourth coil, ending around residue $107 \pm 3$. The onset of the folding transition is between constructs $[L=139]$ and [ $L=143]$, Fig. 3, meaning that folding commences when PENT residue 107 is 32-36 residues away from the peptidyl-tRNA site (P-site) in the ribosome. This places the C-terminus of the folded four-coil $\beta$-helix domain in a similar location in the port of the exit tunnel as we previously determined by cryo-EM for spectrin and titin domains tethered 33-35 residues away from the $\mathrm{P}$-site $[22,24]$, i.e., near a prominent loop in ribosomal protein uL24 at the distal end of the exit tunnel. 


\section{Homology to a stably folded four-coil $\beta$-helix protein}

We performed a pairwise alignment of profile Hidden Markov Models [32] of the full PENT sequence vs, the Protein Data Bank [33] in a search for homologous structures that could explain the folding capabilities of the $[L=150]$ construct. The smallest protein that gave a significant hit was the 98 residues long Nostoc punctiforme PRP Np275 (PDB 2j8i). Using the Dali server [34], we structurally aligned the PENT structure to 2j8i, Fig. 6, giving scores in support of structural homology (Z-score $=$ 13.3; rsmd = 2.0 ̊) [35]. The core Phe residues in PENT mainly align with Leu residues in Np275 (not shown). Strikingly, the structural superimposition between PENT and Np275 covers approximately the same region that was identified as capable of folding by the force-profile analysis (residues 1-97 in Np275 and 10-107 in PENT).

\section{Discussion}

Despite being obvious candidates to be cotranslationally folding proteins, the only $\beta$ helix protein for which there is experimental cotranslational folding data available is the phage P22 tailspike protein, a complex, trimeric protein with a central, 13-coil $\beta$ helix domain in the monomer. Using a panel of conformation-specific monoclonal antibodies to analyze the cotranslational folding of P22 tailspike, it was concluded that more than $\sim 3$ but less than $\sim 7$ coils of the $\beta$-helix must be exposed outside the ribosome for the protein to start to fold into a native-like structure [9].

Here, we have determined the structure and analyzed the cotranslational folding of the much simpler and more regular pentapeptide repeat $\beta$-helix protein PENT from Clostridium botulinum. The structure of PENT is broadly similar to that of MfpA [13], the founding member of the PRP family, except that MfpA lacks the N-terminal 
$\alpha$-helix present in PENT. PENT is also structurally similar to the fourth luminal domain of the human synaptic vesicle protein $2 \mathrm{C}(\mathrm{SV} 2 \mathrm{C})$, which is a receptor for botulinum neurotoxin serotypes A, D and F from Clostridium botulinum [36]. The fact that PENT is present in this bacterium while being similar to the receptor for the neurotoxin it produces is interesting. The fold might hint at the function of the extracellular domain of SV2; it is possible that this domain "mimics" polynucleotides and interacts with DNA- and/or RNA-binding proteins.

Using an arrest-peptide assay that allows us to measure the force generated on the nascent chain by cotranslational folding of PENT, we detect two clear folding transitions: one that involves PENT residues 1 to $\sim 107$, i.e., approximately the first four coils of the eight-coil $\beta$-helix, and one when the full 217-residue PENT domain emerges from the ribosome exit tunnel. It is clear from the force-profile analysis that the first folding transition starts when the C-terminal end of the fourth coil is $\sim 34$ residues away from the P-site, at the distal end of the exit tunnel. The subsequent appearance of the remaining coils does not generate appreciable force on the nascent chain until the entire PENT moiety appears in the exit port, suggesting that PENT folds in two steps, where the first step represents folding of the first four coils, and the second represents the addition of the remaining four coils and the C-terminal capping helix to the folded structure.

Interestingly, the four-coil folding unit in PENT (residues 1 to 107 ) has significant sequence and structural similarity to the small four-coil PRP Np275 from Nostoc punctiforme, suggesting that the four-coil motif may reflect the minimal size of a stable $\beta$-helix. 


\section{Materials and Methods}

Enzymes and chemicals. All restriction and DNA modifying enzymes were purchased from Thermo Scientific (Waltham, MA, USA) and New England Biolabs (Ipswich, MA, USA). Oligonucleotides for cloning and mutagenesis were obtained from MWG Eurofins (Ebersberg, Germany). DNA/RNA purification kits were from Thermo Scientific (Waltham, MA, USA). The PUREexpress ${ }^{\mathrm{TM}}$ cell-free coupled transcriptiontranslation system was from New England Biolabs (Ipswich, MA, USA). [ $\left.{ }^{35} \mathrm{~S}\right]-$ Methionine was purchased from PerkinElmer (Waltham, MA, USA). All other reagents were from Sigma-Aldrich (St. Louis, MO, USA).

DNA manipulations. All PENT constructs were made from a previously described pET19b-derived plasmid (Novagen, Madison, WI, USA) containing a soluble, nonmembrane segment of the lepB gene, the small zinc finger domain ADR1a flanked by GSGS, a 39 residues long linker also derived from the lepB gene (see Supplementary Table S2 for details), the E. coli SecM arrest peptide, FSTPVWISQAQGIRAGP, and a 23-residue C-terminal tail, under the control of a T7 promoter [14]. The GSGSflanked ADRla gene was replaced with the 217 residue M. tuberculosis PENT gene, using the megaprimer approach. C-terminal truncations of PENT and the lepB-derived linker (Supplementary Table S2) were generated by PCR using partially overlapping primers, as previously described [18]. Site-directed mutagenesis was performed to generate constructs with the non-functional FSTPVWISQAQGIRAG $\underline{A}$ SecM AP as full-length controls for all constructs, to replace the Pro at the end of the AP with a stop codon as arrest controls for all constructs, and on the truncated PENT [ $L=150]$ and $[L=161]$ constructs to introduce Phe $\rightarrow$ Ala mutations in the PENT hydrophobic core. Cumulative mutations were introduced by site-directed mutagenesis using partially overlapping primers, and mutations of paired Phe residues in the 
hydrophobic core of PENT were introduced by Gibson assembly [37] using synthetic gene fragments encompassing the mutations (GeneArt Strings, Thermo Scientific, Waltham, MA, USA). All constructs were verified by DNA sequencing.

Expression in vitro. In vitro coupled transcription-translation was performed in PURExpress $^{\mathrm{TM}}$ (New England Biolabs, Ipswich, MA, USA), according to the manufacturer's instructions, using PCR products as templates for the generation of truncated nascent chains. Briefly, $1 \mu \mathrm{l}(50 \mathrm{ng})$ of PCR template and $10 \mu \mathrm{Ci}(1 \mu \mathrm{l})$ $\left[{ }^{35} \mathrm{~S}\right]-$ Methionine were added to a final volume of $10 \mu 1$ reaction components. Transcription-translation was carried out for $20 \mathrm{~min}$. at $750 \mathrm{rpm}$ in a bench-top tube shaker at $37^{\circ} \mathrm{C}$. Reactions were stopped by adding equal volumes of ice-cold $30 \%$ trichloacetic acid, incubated on ice for $30 \mathrm{~min}$, and then centrifuged at 14,000 rpm $(20,800 \mathrm{x} \mathrm{g})$ at $4^{\circ} \mathrm{C}$ for $10 \mathrm{~min}$. in an Eppendorf centrifuge. Pellets were resuspended in $20 \mu \mathrm{l}$ of SDS Sample Buffer and treated with RNase A $\left(400 \mu \mathrm{g} \mathrm{ml}^{-1}\right)$ for $15 \mathrm{~min}$. at $37^{\circ} \mathrm{C}$. Proteins were separated by SDS-PAGE, visualized on a Fuji FLA-9000 phosphoimager, and quantified using ImageGauge software V4.23 (FujiFilm Corporation). Analysis of quantified bands was performed using EasyQuant (in-house developed quantification software). Values of $f_{\mathrm{FL}}$ were calculated as $f_{\mathrm{FL}}=I_{\mathrm{FL}} /\left(I_{\mathrm{FL}}+\right.$ $I_{\mathrm{A}}$ ), where $I_{\mathrm{FL}}$ is the intensity of the band corresponding to the full-length protein, and $I_{\mathrm{A}}$ is the intensity of the band corresponding to the arrested form of the protein. Experiments were repeated at least three times, and SEMs were calculated.

Protein expression and purification. PENT was expressed in E. coli BL21(DE3) T1R pRARE2, grown in TB supplemented with $8 \mathrm{~g} / 1$ glycerol and $0.4 \%$ glucose, with 50 $\mu \mathrm{g} / \mathrm{ml}$ kanamycin and $34 \mu \mathrm{g} / \mathrm{ml}$ chloramphenicol at $37^{\circ} \mathrm{C}$. After $\mathrm{OD}_{600}$ of 2 was reached the temperature was lowered to $18^{\circ} \mathrm{C}$ and expression was induced with 0.5 $\mathrm{mM}$ of IPTG. Protein expression continued overnight, and cells were harvested by 
centrifugation (10 min. at 4,500 g) the next morning. Cell pellets were resuspended $100 \mathrm{mM}$ HEPES pH 8.0, $500 \mathrm{mM} \mathrm{NaCl}, 10 \%$ glycerol, $10 \mathrm{mM}$ imidazole, $0.5 \mathrm{mM}$ TCEP. A tablet of Complete EDTA-free protease inhibitor cocktail (Roche) and 5 $\mu \mathrm{l} / \mathrm{ml}$ benzonase nuclease ( $250 \mathrm{U}$, Sigma) were added to the resuspension, and cells were lysed by pulsed sonication ( $4 \mathrm{~s}$ on/4 s off for $3 \mathrm{~min} ., 80 \%$ amplitude in a VibraCell Sonics sonicator). The lysate was centrifuged for $20 \mathrm{~min}$. at 49,000 g and the supernatant was collected and filtered through a $0.45 \mu \mathrm{m}$ pore size filter.

A $2 \mathrm{ml}$ His Trap HP column (GE Healthcare) was used for the first purification step. After running the lysate through, the column was washed with IMAC buffer $(20 \mathrm{mM}$ HEPES pH 7.5, $500 \mathrm{mM} \mathrm{NaCl}, 10 \%$ glycerol, $0.5 \mathrm{mM}$ TCEP) containing $10 \mathrm{mM}$ imidazole. A second wash was performed with IMAC buffer containing $50 \mathrm{mM}$ imidazole, and the protein was eluted with IMAC buffer containing $500 \mathrm{mM}$ imidazole. The elution fraction was loaded onto a HiLoad 16/60 Superdex 75 column (GE Healthcare) as a second purification step. Fractions were examined on an SDSPAGE gel, and TCEP was added up to $2 \mathrm{mM}$ concentration before pooling and concentrating with a centrifugal concentrator.

Crystallization and structure determination. PENT crystals were found in the A6 condition of the PACT premier screen (Molecular Dimensions). In order to optimize these, $150 \mathrm{nl}$ of protein solution was mixed with $50 \mathrm{nl}$ of reservoir solution $(0.1 \mathrm{M}$ SPG buffer $\mathrm{pH} 9.5,25 \%$ PEG 1500) in a sitting-drop crystallization plate. Long thin rod-shaped crystals grew overnight, and were flash frozen in liquid nitrogen after transfer to a drop of cryo-protecting solution (0.1 M SPG buffer pH 9.5, 6.6 mM HEPES pH 7.5, $100 \mathrm{mM} \mathrm{NaCl,} \mathrm{10 \%} \mathrm{glycerol,} \mathrm{25 \%} \mathrm{w/v} \mathrm{PEG} \mathrm{1500).} \mathrm{X-ray} \mathrm{diffraction}$ data collection was performed at beamline i03, Diamond Light Source (Oxford, UK). The data were processed using DIALS [38], molecular replacement was performed 
using Phaser [39] with a model provided by the Phyre ${ }^{2}$ server [40]. The model was built using Phenix Autobuild [41] and Coot [42], and the structure was refined using Refmac5 [43]. Data processing and refinement statistics are presented in Supplementary Table 1. Coordinates for the PENT structure have been deposited in the PDB with the accession code 6FLS.

Sequence and structure comparisons. The hhpred server [44] was used with default parameter settings (https://toolkit.tuebingen.mpg.de/\#/tools/hhpred) to search the PDB database with the full PENT sequence (residues 1-217). The Dali server [34] http://ekhidna2.biocenter.helsinki.fi/dali/ was used with default parameter settings to generate the structural superposition shown in Fig. 6.

Pulse proteolysis. To assess the stability of full-length PENT protein and mutants thereof, we employed a pulse-proteolysis assay [45]. Full-lenght PENT protein (217 residues) was cloned upstream of a 21 residues long linker composed of alternating Gly and Ser residues followed by the $\operatorname{SecM}(M s)$ arrest peptide [46] with the last Pro residue mutated to a stop codon. After in vitro synthesis of radio-labelled protein in the PURE system as described above, the reaction was stopped by addition of chloramphenicol (instead of TCA) at a final concentration of $3.3 \mathrm{mM}$. Each sample was divided in two aliquots of equal volume, one for pulse-proteolysis [31] and the other serving as a non-treated control. Pulse-proteolysis was performed by treatment with thermolysin (buffered in $50 \mathrm{mM}$ Tris, $500 \mu \mathrm{M} \mathrm{ZnCl}_{2}, \mathrm{pH} 7.0$ ) at a final concentration of $0.75 \mathrm{mg} / \mathrm{m}$ for $1 \mathrm{~min}$. at $37^{\circ} \mathrm{C}$, under constant shaking at $700 \mathrm{rpm}$. The same conditions were applied for the non-treated controls with the difference that thermolysin was not included in the buffer solution. The reaction was stopped by addition of $3 \mu 1500 \mathrm{mM}$ EDTA ( $\mathrm{pH} 8.4$ ), and protein precipitation was performed by 
addition of 1:1 volume of ice-cold 10\% TCA and incubation on ice for 30 minutes. As described in the previous section, after centrifugation at $14,000 \mathrm{rpm}$ for 5 minutes at $4^{\circ} \mathrm{C}$, the supernatant was discarded and the pellet was re-suspended in sample buffer at $37^{\circ} \mathrm{C}$ for 15 minutes, under constant shaking at $900 \mathrm{rpm}$. The samples were supplemented with RNase I $(670 \mu \mathrm{g} / \mathrm{mL})$ at $37^{\circ} \mathrm{C}$, for 30 minutes, and were subsequently resolved by SDS/PAGE. All pulse-proteolysis assays were performed in triplicates.

\section{Author contributions}

GvH and PS conceived the project. LN, MMC, and JF designed and performed the experiments. LN, MMC, JF, PS, and GvH wrote the manuscript.

\section{Acknowledgements}

We thank the beamline scientists at DLS, Oxford, BESSY, Berlin, ESRF, Grenoble, Max-Lab, Lund and SLS, Villigen for their support in data collection and PSF for protein production, and Dr. Ola Nilsson (Stockholm) for technical assistance. This work was supported by grants from the Knut and Alice Wallenberg Foundation, the Swedish Cancer Foundation, and the Swedish Research Council to GvH, and by the Swedish Cancer Foundation and the Swedish Research Council (2014-5667) to PS.

\section{References}

[1] Kloss E, Courtemanche N, Barrick D. Repeat-protein folding: new insights into origins of cooperativity, stability, and topology. Arch Biochem Biophys. 2008 469:83-99.

[2] Main ER, Jackson SE, Regan L. The folding and design of repeat proteins: reaching a consensus. Curr Opin Struct Biol. 2003 13:482-489. 
[3] Andrade MA, Perez-Iratxeta C, Ponting CP. Protein repeats: structures, functions, and evolution. J Struct Biol. 2001 134:117-131.

[4] Lupas AN, Ponting CP, Russell RB. On the evolution of protein folds: are similar motifs in different protein folds the result of convergence, insertion, or relics of an ancient peptide world? J Struct Biol. 2001 134:191-203.

[5] Alva V, Soding J, Lupas AN. A vocabulary of ancient peptides at the origin of folded proteins. eLife. 2015 4:e09410.

[6] Junker M, Schuster CC, McDonnell AV, Sorg KA, Finn MC, Berger B, Clark PL. Pertactin beta-helix folding mechanism suggests common themes for the secretion and folding of autotransporter proteins. Proc Natl Acad Sci U S A. 2006 103:49184923.

[7] Khrapunov S, Cheng H, Hegde S, Blanchard J, Brenowitz M. Solution structure and refolding of the Mycobacterium tuberculosis pentapeptide repeat protein MfpA. J Biol Chem. 2008 283:36290-36299.

[8] Nissley DA, Sharma AK, Ahmed N, Friedrich UA, Kramer G, Bukau B, O'Brien EP. Accurate prediction of cellular co-translational folding indicates proteins can switch from post- to co-translational folding. Nat Commun. 2016 7:10341.

[9] Evans MS, Sander IM, Clark PL. Cotranslational folding promotes $\beta$-helix formation and avoids aggregation in vivo. J Mol Biol. 2008 383:683-692. [10] Lee W, Zeng X, Zhou HX, Bennett V, Yang W, Marszalek PE. Full reconstruction of a vectorial protein folding pathway by atomic force microscopy and molecular dynamics simulations. J Biol Chem. 2010 285:38167-38172.

[11] Vetting MW, Hegde SS, Fajardo JE, Fiser A, Roderick SL, Takiff HE, Blanchard JS. Pentapeptide repeat proteins. Biochemistry. 2006 45:1-10. 
[12] Shah S, Heddle JG. Squaring up to DNA: pentapeptide repeat proteins and DNA mimicry. Appl Microbiol Biotechnol. 2014 98:9545-9560.

[13] Hegde SS, Vetting MW, Roderick SL, Mitchenall LA, Maxwell A, Takiff HE, Blanchard JS. A fluoroquinolone resistance protein from Mycobacterium tuberculosis that mimics DNA. Science. 2005 308:1480-1483.

[14] Nilsson OB, Hedman R, Marino J, Wickles S, Bischoff L, Johansson M, MullerLucks A, Trovato F, Puglisi JD, O'Brien EP, Beckmann R, von Heijne G.

Cotranslational protein folding inside the ribosome exit tunnel. Cell Rep. 2015 $12: 1533-1540$.

[15] Vetting MW, Hegde SS, Hazleton KZ, Blanchard JS. Structural characterization of the fusion of two pentapeptide repeat proteins, Np275 and Np276, from Nostoc punctiforme: resurrection of an ancestral protein. Protein Sci. 2007 16:755-760. [16] Ito K, Chiba S, Pogliano K. Divergent stalling sequences sense and control cellular physiology. Biochem Biophys Res Comm. 2010 393:1-5.

[17] Butkus ME, Prundeanu LB, Oliver DB. Translocon "pulling" of nascent SecM controls the duration of its translational pause and secretion-responsive secA regulation. J Bacteriol. 2003 185:6719-6722.

[18] Ismail N, Hedman R, Schiller N, von Heijne G. A biphasic pulling force acts on transmembrane helices during translocon-mediated membrane integration. Nature Struct Molec Biol. 2012 19:1018-1022.

[19] Goldman DH, Kaiser CM, Milin A, Righini M, Tinoco I, Bustamante C. Mechanical force releases nascent chain-mediated ribosome arrest in vitro and in vivo. Science. 2015 348:457-460. 
[20] Cymer F, von Heijne G. Cotranslational folding of membrane proteins probed by arrest-peptide-mediated force measurements. Proc Natl Acad Sci U S A. 2013 110:14640-14645.

[21] Ismail N, Hedman R, Lindén M, von Heijne G. Charge-driven dynamics of nascent-chain movement through the SecYEG translocon. Nat Struct Mol Biol. 2015 22:145-149.

[22] Nilsson OB, Nickson AA, Hollins JJ, Wickles S, Steward A, Beckmann R, von Heijne G, Clarke J. Cotranslational folding of spectrin domains via partially structured states. Nat Struct Mol Biol. 2017 24:221-225.

[23] Nilsson OB, Müller-Lucks A, Kramer G, Bukau B, von Heijne G. Trigger factor reduces the force exerted on the nascent chain by a cotranslationally folding protein. $\mathrm{J}$ Mol Biol. 2016 428:1356-1364.

[24] Tian P, Steward A, Kudva R, Su T, Shilling PJ, Nickson AA, Hollins JJ, Beckmann R, von Heijne G, Best RB, Clarke J. The folding pathway of an Ig domain is conserved on and off the ribosome. Proc Natl Acad Sci U S A. 2018 in press.

[25] Kudva R, Pardo-Avila F, Sandhu H, Carroni M, Bernstein HD, von Heijne G.

The shape of the ribosome exit tunnel affects cotranslational protein folding. BioRxiv. 2018 doi: https://doi.org/10.1101/274191.

[26] Farias-Rico JA, Ruud Selin F, Myronidi I, Frühauf M, von Heijne G. Effects of protein size, thermodynamic stability, and net charge on cotranslational folding on the ribosome. Proc Natl Acad Sci U S A. 2018 115:E9280-E9287.

[27] Marsden AP, Hollins JJ, O’Neill C, Ryzhov P, Higson S, Mendonca CATF, Kwan TO, Kwa LG, Steward A, Clarke J. Investigating the effect of chain connectivity on the folding of a $\beta$-sheet protein on and off the ribosome. J Mol Biol. 2018 in press. 
[28] Nakatogawa H, Ito K. Secretion monitor, SecM, undergoes self-translation arrest in the cytosol. Mol Cell. 2001 7:185-192.

[29] Shimizu Y, Kanamori T, Ueda T. Protein synthesis by pure translation systems. Methods. 2005 36:299-304.

[30] Bryan AW, Jr., Starner-Kreinbrink JL, Hosur R, Clark PL, Berger B. Structurebased prediction reveals capping motifs that inhibit beta-helix aggregation. Proc Natl Acad Sci U S A. 2011 108:11099-11104.

[31] Park C, Marqusee S. Pulse proteolysis: a simple method for quantitative determination of protein stability and ligand binding. Nat Methods. 2005 2:207-212. [32] Söding J. Protein homology detection by HMM-HMM comparison.

Bioinformatics. 2005 21:951-960.

[33] Berman HM, Westbrook J, Feng Z, Gilliland G, Bhat TN, Weissig H, Shindyalov IN, Bourne PE. The Protein Data Bank. Nucl Acids Res. 2000 28:235-242.

[34] Holm L, Laakso LM. Dali server update. Nucleic Acids Res. 2016 44:W351-355. [35] Holm L, Sander C. Touring protein fold space with Dali/FSSP. Nucleic Acids Res. 1998 26:316-319.

[36] Benoit RM, Frey D, Hilbert M, Kevenaar JT, Wieser MM, Stirnimann CU, McMillan D, Ceska T, Lebon F, Jaussi R, Steinmetz MO, Schertler GF, Hoogenraad CC, Capitani G, Kammerer RA. Structural basis for recognition of synaptic vesicle protein $2 \mathrm{C}$ by botulinum neurotoxin A. Nature. 2014 505:108-111.

[37] Gibson DG, Young L, Chuang RY, Venter JC, Hutchison CA, 3rd, Smith HO. Enzymatic assembly of DNA molecules up to several hundred kilobases. Nat Methods. 2009 6:343-345. 
[38] Waterman DG, Winter G, Gildea RJ, Parkhurst JM, Brewster AS, Sauter NK,

Evans G. Diffraction-geometry refinement in the DIALS framework. Acta Crystallogr D Struct Biol. 2016 72:558-575.

[39] McCoy AJ, Grosse-Kunstleve RW, Adams PD, Winn MD, Storoni LC, Read RJ. Phaser crystallographic software. J Appl Crystallogr. 2007 40:658-674.

[40] Kelley LA, Mezulis S, Yates CM, Wass MN, Sternberg MJ. The Phyre2 web portal for protein modeling, prediction and analysis. Nature protocols. 2015 10:845858.

[41] Adams PD, Afonine PV, Bunkoczi G, Chen VB, Davis IW, Echols N, Headd JJ, Hung LW, Kapral GJ, Grosse-Kunstleve RW, McCoy AJ, Moriarty NW, Oeffner R, Read RJ, Richardson DC, Richardson JS, Terwilliger TC, Zwart PH. PHENIX: a comprehensive Python-based system for macromolecular structure solution. Acta Crystallogr D Biol Crystallogr. 2010 66:213-221.

[42] Emsley P, Cowtan K. Coot: model-building tools for molecular graphics. Acta Crystallogr D Biol Crystallogr. 2004 60:2126-2132.

[43] Murshudov GN, Skubak P, Lebedev AA, Pannu NS, Steiner RA, Nicholls RA, Winn MD, Long F, Vagin AA. REFMAC5 for the refinement of macromolecular crystal structures. Acta Crystallogr D Biol Crystallogr. 2011 67:355-367.

[44] Söding J, Biegert A, Lupas AN. The HHpred interactive server for protein homology detection and structure prediction. Nucleic Acids Res. 2005 33:W244-248. [45] Samelson AJ, Jensen MK, Soto RA, Cate JH, Marqusee S. Quantitative determination of ribosome nascent chain stability. Proc Natl Acad Sci U S A. 2016 113:13402-13407. 
[46] Cymer F, Hedman R, Ismail N, von Heijne G. Exploration of the arrest peptide sequence space reveals arrest-enhanced variants. J Biol Chem. 2015 290:1020810215.

\section{Figure legends}

Figure 1. Structural representation of the C. botulinum PENT protein. (a) Crystal structure of the PENT dimer. Chains are colored in rainbow from $\mathrm{N}$ terminus (blue) to C terminus (red). (b) View along the central axis of the PENT monomer, highlighting the Phe residues in the hydrophobic core. N-terminal residues 1-30 have been removed for clarity.

Figure 2. Arrest-peptide based force-measurement assay. (a) Schematic scenario for constructs generating $(F>0)$ or not generating $(F \approx 0)$ pulling force depending on the location of the PENT domain relative to the arrest peptide. (b) The force-generating PENT domain (and C-terminal truncations thereof; blue) is connected, via a variablelength linker (brick red) and an "insulating" SGSG tetrapeptide (grey), to the 17residue SecM arrest peptide (AP; red). An N-terminal 154-residue segment from the E.coli LepB protein (light blue) and a short GSGS segment (grey) is included in all constructs of total length $L \leq 216$ (where $L$ is the number of residues between the Nterminal end of the PENT part and the last residue in the AP) in order to make short PENT constructs conveniently amenable to analysis by SDS-PAGE, and a 23-residue C-terminal tail (also from LepB) is appended at the C terminus in order to make it possible to separate arrested (A) and full-length (FL) chains by SDS-PAGE. The hatched area highlights the $\beta$-helix fold within PENT. The lengths of the different parts of the construct are indicated. (c) SDS-PAGE gels showing full-length (FL, black circle) and arrested (A, white circle) species for the [ $L=150]$ construct (lane 2); 
bands just below the A band are presumably due to ribosomal stacking. Lane 1 shows a control construct with a Pro $\rightarrow$ Ala mutation at the C-terminal end of the AP that prevents translational arrest, and serves as a marker for the full-length form of the protein. Lane 3 shows a control construct with a stop codon replacing the C-terminal Pro codon in the AP, and serves as a marker for the arrested form of the protein. The measured $f_{F L}$ value for the $[L=150]$ construct is shown below the gel.

Figure 3. Force profile for the full set of C-terminal truncations of PENT. The four peaks discussed in the text are indicated. The arrow at $L=238$ residues indicates the shortest construct with the full-length-residue 217 PENT domain (also including the SGSS segment and the 17-residue AP); shorter constructs have C-terminal deletions in the PENT domain and longer constructs have linker segments of 0-39 residues (brick red in Fig. 2b). All experiments were repeated at least 3 times; averages $\pm \mathrm{SE}$ are shown.

Figure 4. Effects of mutations in the hydrophobic core of the $[L=150]$ construct (includes PENT residues 1-129). (a) The N-terminal cap (blue) and $5 \mathrm{~N}$-terminal $\beta$ helix coils (indicated by distinct colors) of PENT (residues 1-129), highlighting the hydrophobic core mutations analyzed: Val15, Phe18, 47, 57, 67, 77, 87, 97, 122, and 127. All amino acids were mutated to Ala in a cumulative or paired fashion. (b) Effect of the double mutant V15A+F18A in the N-terminal cap. (c) Effects of cumulative Phe $\rightarrow$ Ala mutations in the hydrophobic core of PENT. (d) Effects of paired Phe $\rightarrow$ Ala mutations in the hydrophobic core of PENT. All experiments were repeated at least 3 times; averages $\pm \mathrm{SE}$ are shown. N.S.: not significant, $* p \leq 0.05, * * \mathrm{p} \leq 0.01, * * * p \leq$ 0.001 . Note that the average $f_{F L}$ value for the $[L=150]$ construct (included as a control in all experiments) is somewhat variable, due to different batches of PURE being used for panels $b-d$. 
Figure 5. Effect of cumulative replacement of amino acids at the C-terminal end of the PENT moiety in the $[L=150]$ construct. (a) Schematic representation of the replacement strategy with alternating Gly and Ser residues, five at a time. (b) Effects of the cumulative replacements. All experiments were repeated at least 3 times; averages \pm SE are shown. ${ }^{* *} \mathrm{p} \leq 0.01,{ }^{* * *} p \leq 0.001$.

Figure 6. Structural superimposition of PENT and Np275 (PDB 2J8I). The folding unit (PENT residues 1-107) determined by the force-profile analysis is boxed in red. 
bioRxiv preprint doi: https://doi.org/10.1101/255810; this version posted October 23, 2018. The copyright holder for this preprint (which was not certified by peer review) is the author/funder, who has granted bioRxiv a license to display the preprint in perpetuity. It is made available under aCC-BY-NC-ND 4.0 International license.
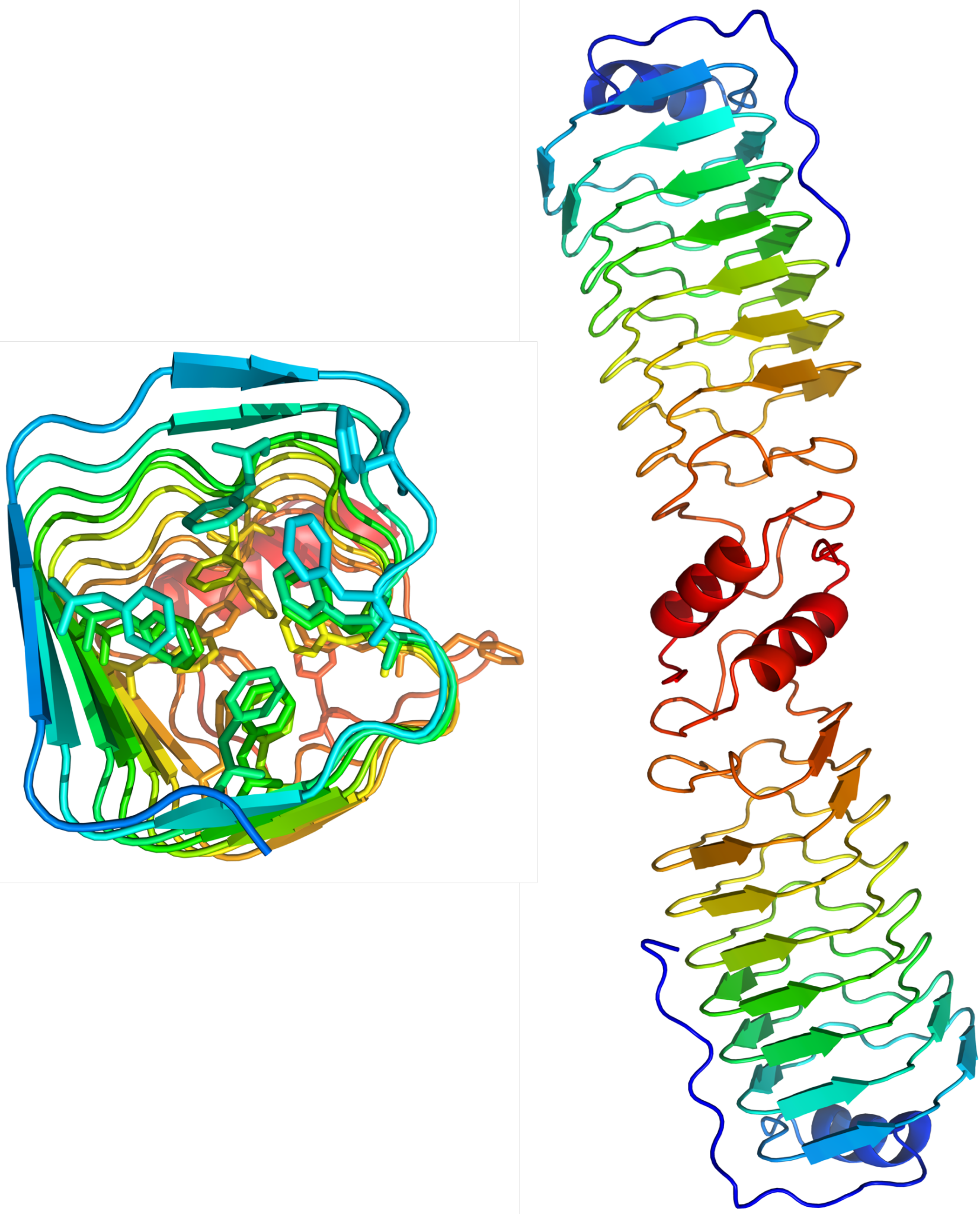

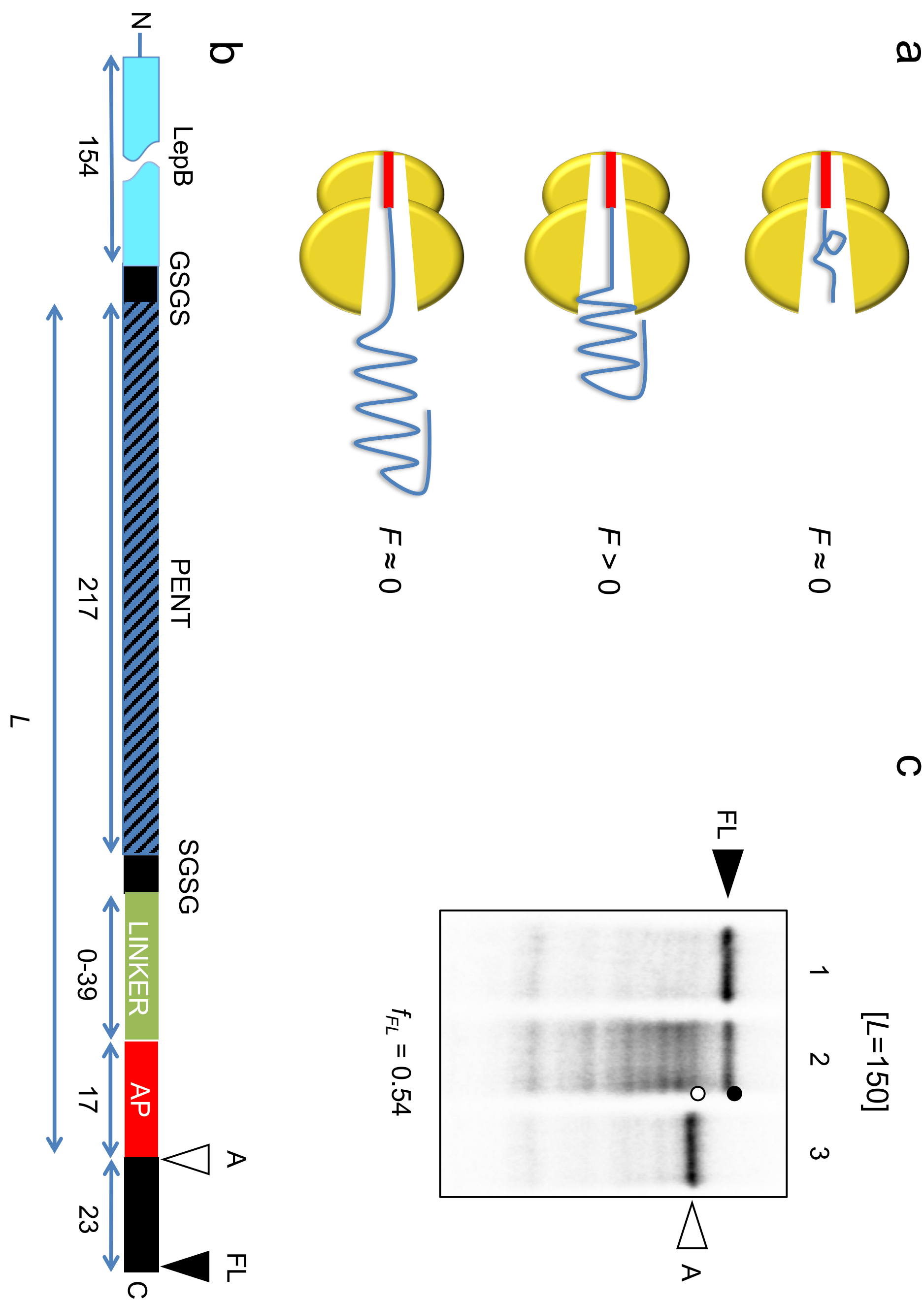


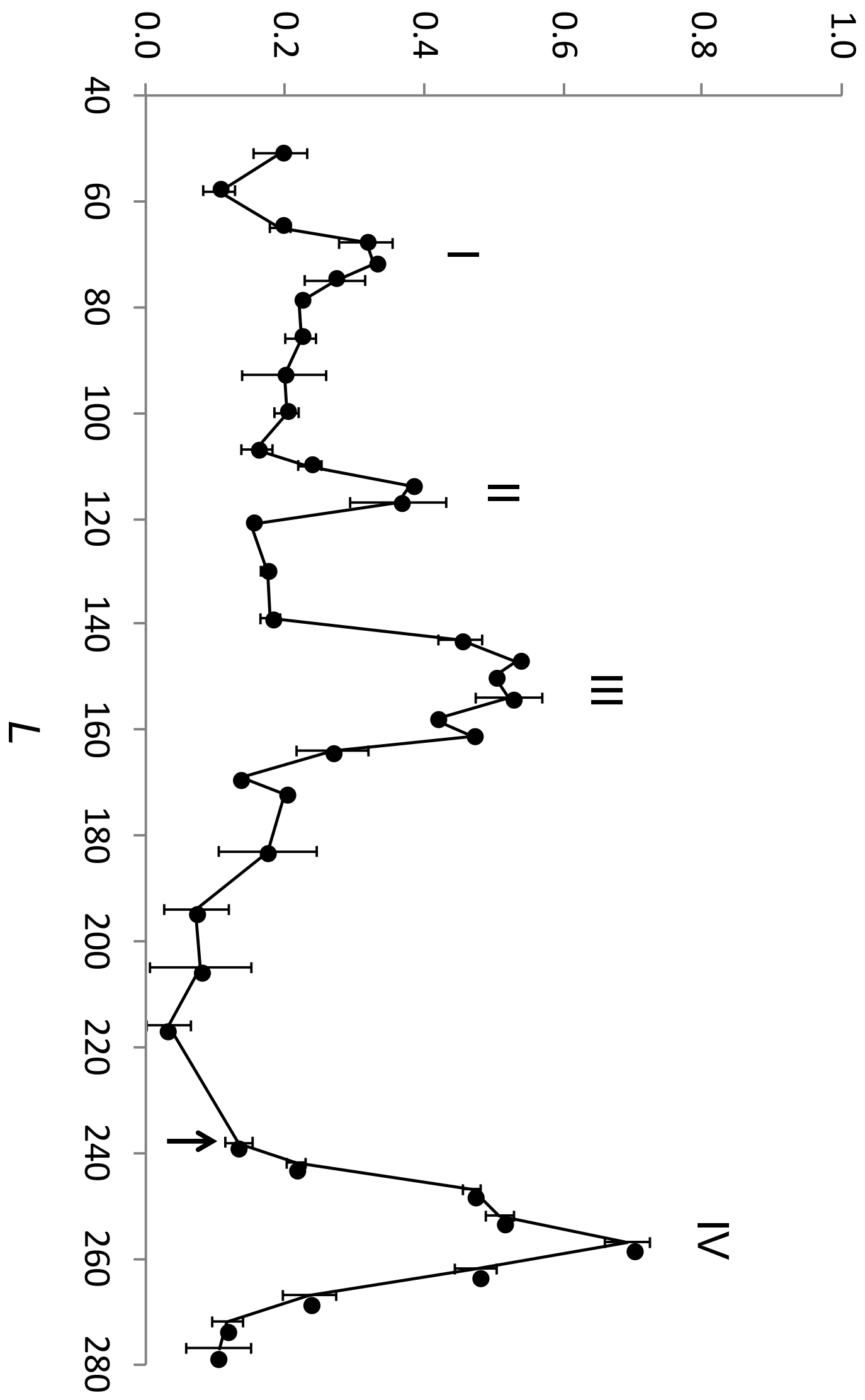


bioRxiv preprint doi: https://doi.org/10.1101/255810; this version posted October 23, 2018. The copyright holder for this preprint (which was not certified by peer review) is the author/funder, who has granted bioRxiv a license to display the preprint in perpetuity. It is made available under aCC-BY-NC-ND 4.0 International license.

뭄.

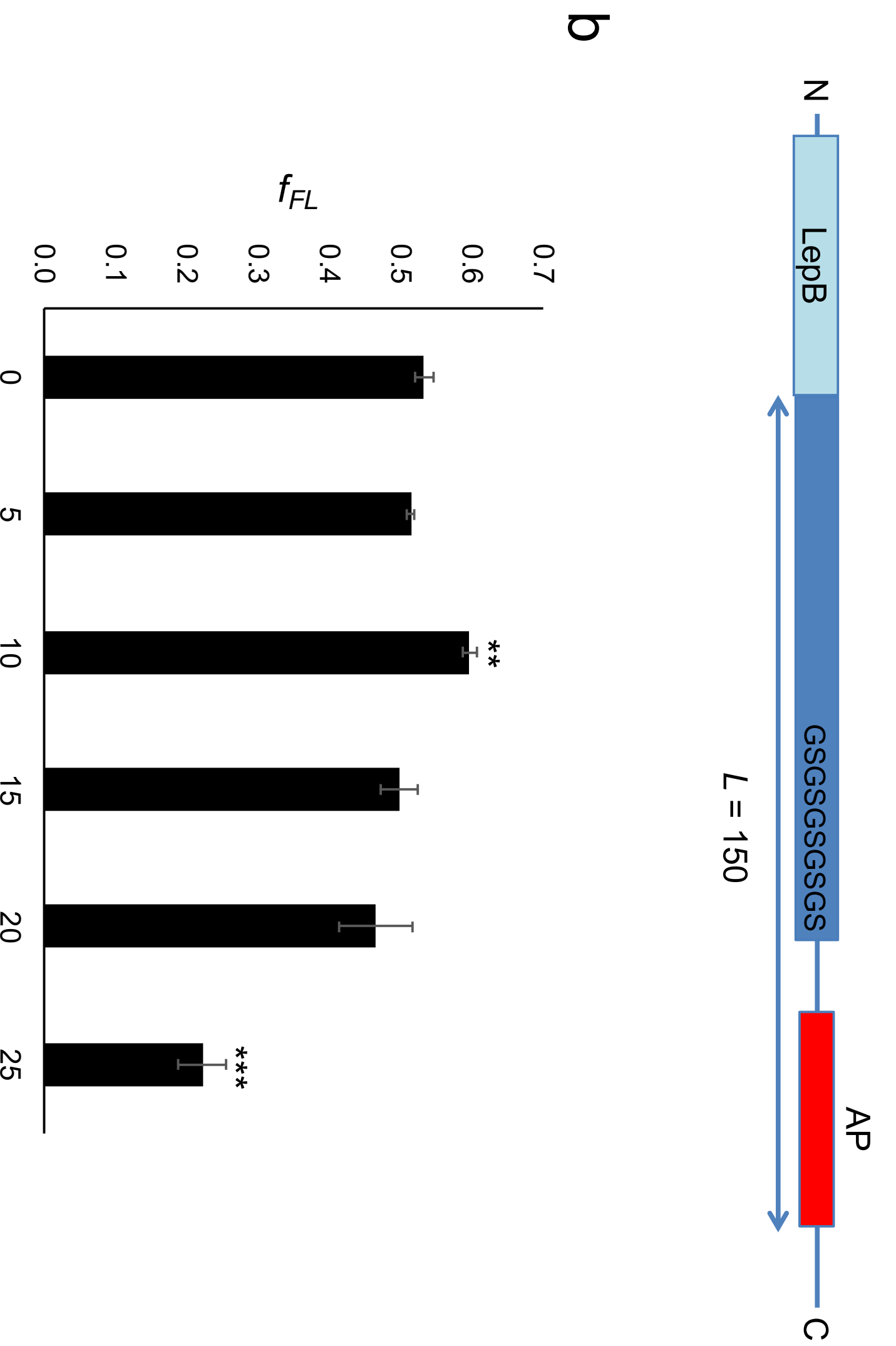


חำ

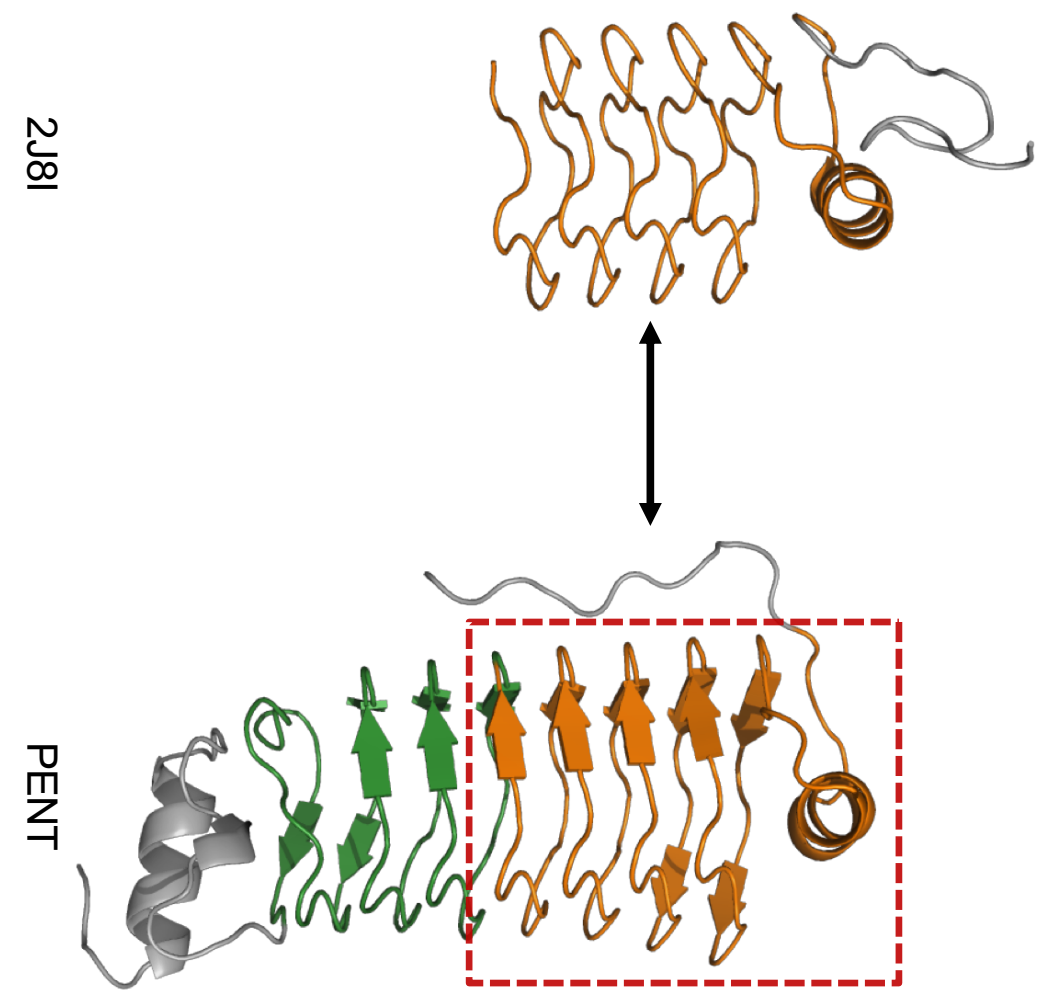




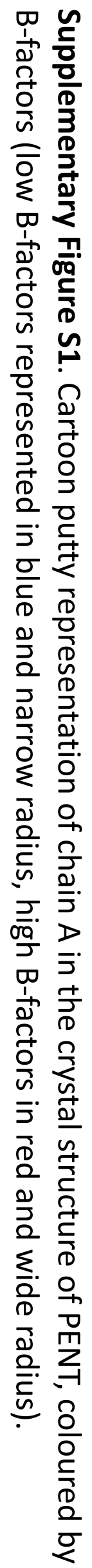

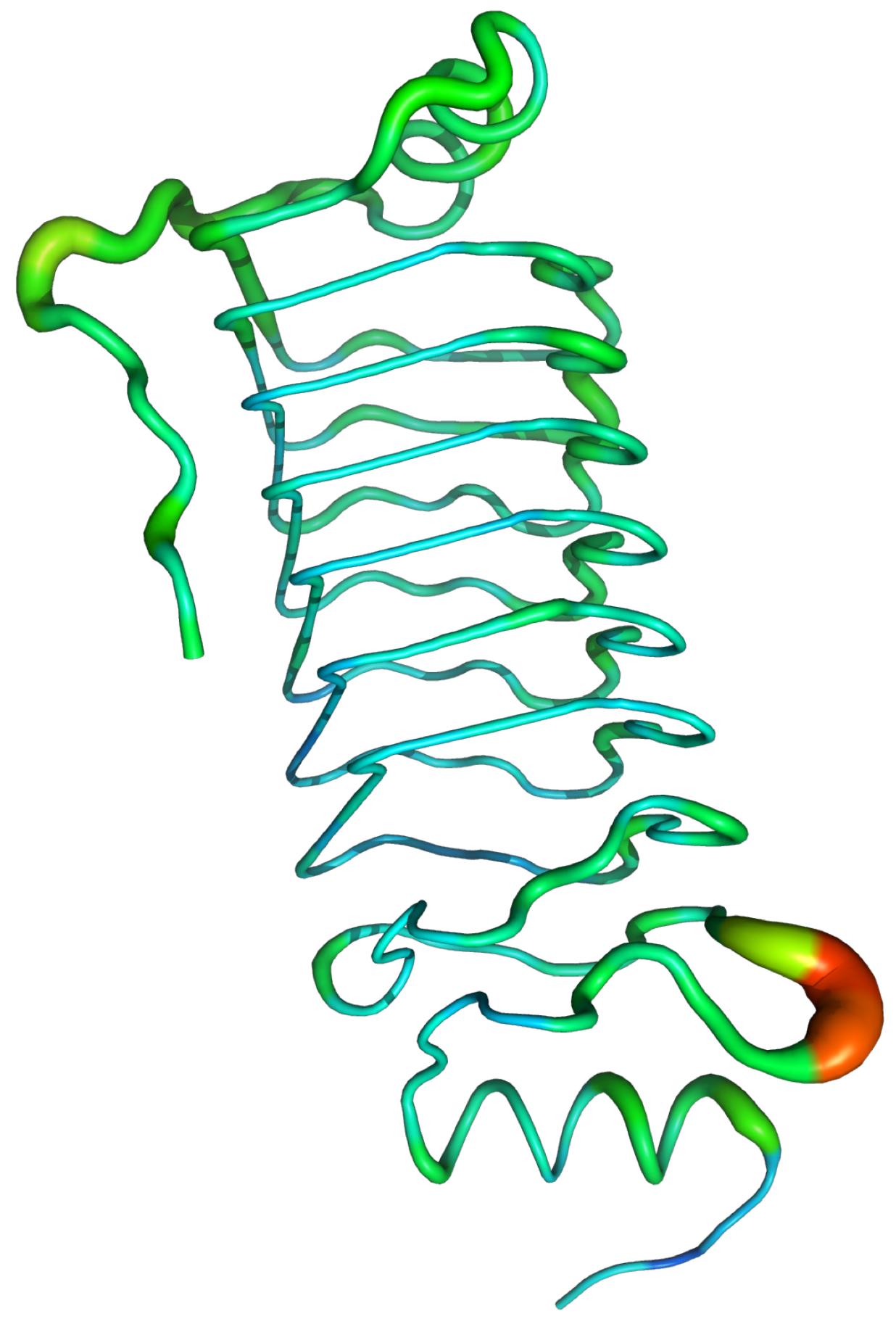




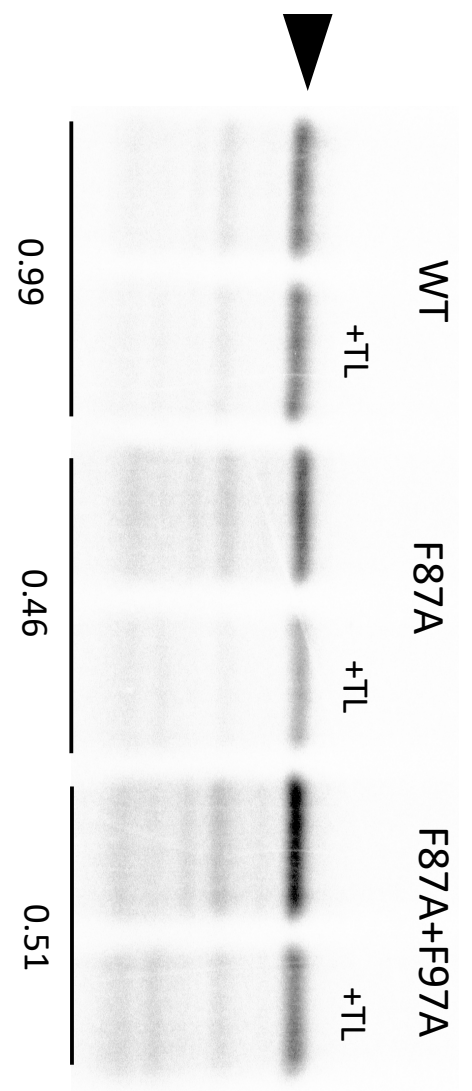

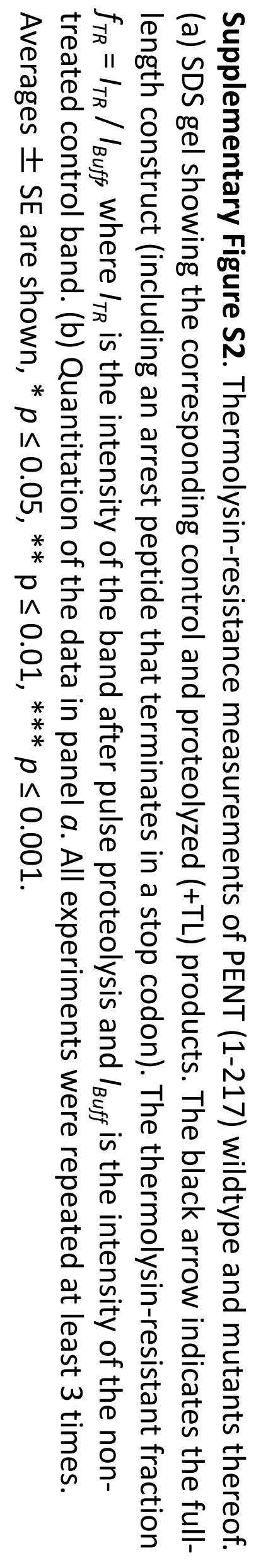

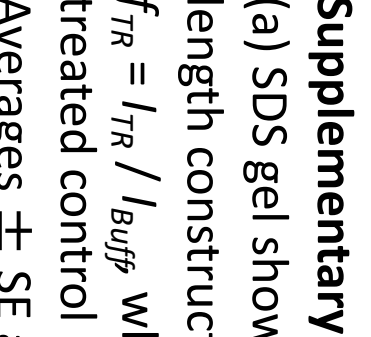

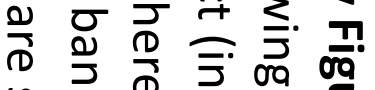

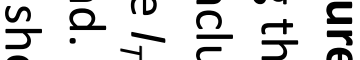

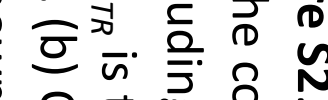

* 둥 ڤ

○

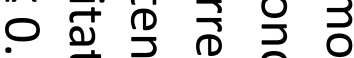

ज 을 芦 宁

* 옹욤ㅇ 음

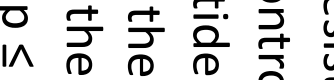

음 + 으 문

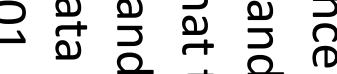

* इ Q

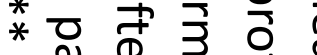

1

政

0 D

음

정 둥두

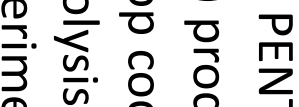

익 응 든

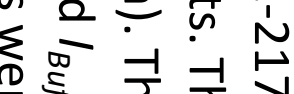

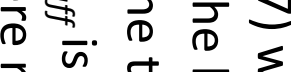

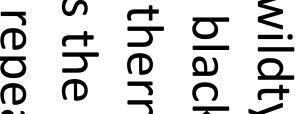

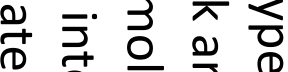

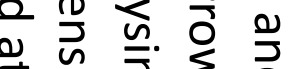

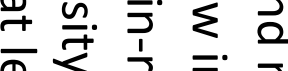

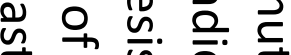

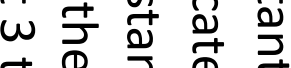

†. D

产穴 完

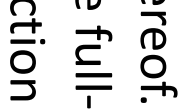

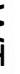

$\underset{D}{\infty}$

צִ

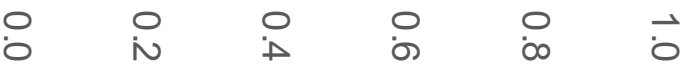

$\lesssim$

$f_{T R}$

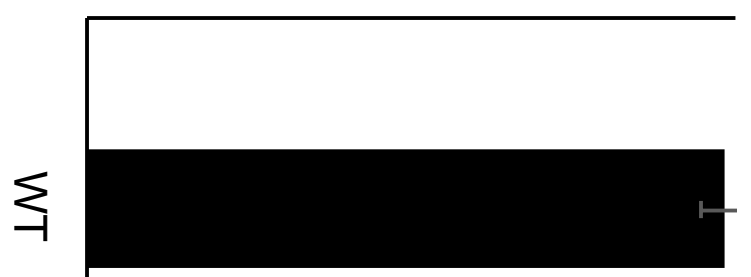

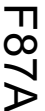

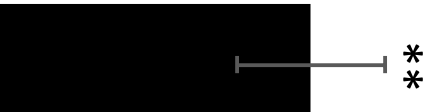

T
$\stackrel{D}{D}$
+
$\stackrel{T}{D}$ 


\section{Supplementary Table 1}

Data processing and refinement statistics for PENT (PDB access code 6FLS).

\begin{tabular}{lc} 
Space group & P 21 \\
$\begin{array}{l}\text { Unit cell parameters } a, b, c \\
(\AA)\end{array}$ & $107.8,108.5,112.9$ \\
Resolution $(\AA)$ & 2.8 \\
$I / \sigma(I)$ & $10.1(1.8)$ \\
Half-set correlation CC(1/2) & $0.997(0.672)$ \\
Completeness (\%) & $99.2(99.5)$ \\
Multiplicity & $3.8(3.9)$ \\
$\mathrm{R}_{\text {merge }}$ & $0.099(0.778)$ \\
$\mathrm{R}_{\text {cryst }}(\%)$ & 17.0 \\
$\mathrm{R}_{\text {free }}(\%)$ & 20.5 \\
RMSD in bond length $(\AA)$ & 0.009 \\
RMSD in bond angle $(\AA)$ & 1.357 \\
Ramachandran plot $(\%)$ & 1.75 \\
$\quad$ In preferred regions & 0.12 \\
$\quad$ In allowed regions & 98.13 \\
\hline
\end{tabular}




\section{Supplementary Table 2}

Amino acid sequences of the full-length [Lep154]-PENT-linker-SecM-C-terminal

tail construct and of the truncations analyzed in the paper. Note that the $\mathrm{N}$-terminal

Lep-part is not present in constructs with $L \geq 238$ residues (that all contain the full

217-residue PENT domain).

\begin{tabular}{|c|c|}
\hline $\begin{array}{l}{[L=277]} \\
\text { (full-length } \\
\text { PENT) }\end{array}$ & $\begin{array}{l}\text { MSISNPRIPADLIMVDDFSSYAQGYLYEEIPITQIKIYGEHIEYFDFSKSEINTSIFENCTFLDCSFEG } \\
\text { ASFVDVVFQNCNLSNSNFTDAYFERCFIACKCVGVNMIDTIFKQTSMQRSNFQYSYFDKAKMTDIAFEDIDF } \\
\text { TEVSITEAKLKRFKAKNSHFIKNNFFKTMLTGVDFTKNELVAPTVSSPPIEFQGAKISMVQAADLIGLWGIIV } \\
\text { EQSGSGFAYGIKDPIYQKTLVPGQQNATWIVPPGQYFMMGDWMS SFSTPVISQAQGIRAGPGSSDKQEGEWP } \\
\text { TGLRLSRIGGIH }\end{array}$ \\
\hline $\begin{array}{l}\quad[L=272] \\
\text { (full-length } \\
\text { PENT) }\end{array}$ & $\begin{array}{l}\text { MSISNPRIPADLIMVDDFSSYAQGYLYEEIPITQIKIYGEHIEYFDFSKSEINTSIFENCTFLDCSFEG } \\
\text { ASFVDVVFQNCNLSNSNFTDAYFERCQFIACKCVGVNMIDTIFKQTSMQRSNFQYSYFDKAKMTDIAFEDIDF } \\
\text { TEVSITEAKLKRFKAKNSHFIKNNFFKTMLTGVDFTKNELVAPTVSSPPIEFQGAKISMVQAADLIGLWGIIV } \\
\text { EQSGSGKDPIYQKTLVPGQQNATWIVPPGQYFMMGDWMSSFSTPVWISQAQGIRAGPGSSDKQEGEWPTGLRL } \\
\text { SRIGGIH* }\end{array}$ \\
\hline $\begin{array}{l}\quad[L=267] \\
\text { (full-length } \\
\text { PENT) }\end{array}$ & $\begin{array}{l}\text { MSISNPRIPADLIMVDDFSSYAQGYLYEEIPITQIKIYGEHIEYFDFSKSEINTSIFENCTFLDCSFEG } \\
\text { ASFVDVVFQNCNLSNSNFTDAYFERCF IACKCVGVNMIDTIFKQTSMQRSNFQYSYFDKAKMTDIAFEDIDF } \\
\text { TEVSITEAKLKRFKAKNSHFIKNNFFKTMLTGVDFTKNELVAPTVSSPPIEFQGAKISMVQAADLIGLWGIIV } \\
\text { EQSGSGQKTLVPGQQNATWIVPPGQYFMMGDWMSSFSTPVWISQAQGIRAGPGSSDKQEGEWPTGLRLSRIGG } \\
\text { IH }\end{array}$ \\
\hline $\begin{array}{l}{[L=262]} \\
\text { (full-length } \\
\text { PENT) }\end{array}$ & $\begin{array}{l}\text { MSISNPRIPADLIMVDDFSSYAQGYLYEEIPITQIKIYGEHIEYFDFSKSEINTSIFENCTFLDCSFEG } \\
\text { ASFVDVVFQNCNLSNSNFTDAYFERCQFIACKCVGVNMIDTIFKQTSMQRSNFQYSYFDKAKMTDIAFEDIDF } \\
\text { TEVSITEAKLKRFKAKNSHFIKNNFFKTMLTGVDFTKNELVAPTVSSPPIEFQGAKISMVQAADLIGLWGIIV } \\
\text { EQSGSGPGQQNATWIVPPGQYFMMGDWMSSFSTPVWISQAQGIRAGPGSSDKQEGEWPTGLRLSRIGGIH }\end{array}$ \\
\hline $\begin{array}{l}\quad[L=257] \\
\text { (full-length } \\
\text { PENT) }\end{array}$ & $\begin{array}{l}\text { MSISNPRIPADLIMVDDFSSYAQGYLYEEIPITQIKIYGEHIEYFDFSKSEINTSIFENCTFLDCSFEG } \\
\text { ASFVDVVFQNCNLSNSNFTDAYFERCQFIACKCVGVNMIDTIFKQTSMQRSNFQYSYFDKAKMTDIAFEDIDF } \\
\text { TEVSITEAKLKRFKAKNSHFIKNNFFKTMLTGVDFTKNELVAPTVSSPPIEFQGAKISMVQAADLIGLWGIIV } \\
\text { EQSGSGATWIVPPGQYFMMGDWMSSFSTPVWISQAQGIRAGPGSSDKQEGEWPTGLRLSRIGGIH }\end{array}$ \\
\hline $\begin{array}{l}\quad[L=252] \\
\text { (full-length } \\
\text { PENT) }\end{array}$ & $\begin{array}{l}\text { MSISNPRIPADLIMVDDFSSYAQGYLYEEIPITQIKIYGEHIEYFDFSKSEINTS IFENCTFLDCSFEG } \\
\text { ASFVDVVFQNCNLSNSNFTDAYFERCQFIACKCVGVNMIDTIFKQTSMQRSNFQYSYFDKAKMTDIAFEDIDF } \\
\text { TEVSITEAKLKRFKAKNSHFIKNNFFKTMLTGVDFTKNELVAPTVSSPPIEFQGAKISMVQAADLIGLWGIIV } \\
\text { EQSGSGPPGQYFMMGDWMSSFSTPVWISQAQGIRAGPGSSDKQEGEWPTGLRLSRIGGIH }\end{array}$ \\
\hline $\begin{array}{l}{[L=247]} \\
\text { (full-length } \\
\text { PENT) }\end{array}$ & $\begin{array}{l}\text { MSISNPRIPADLIMVDDFSSYAQGYLYEEIPITQIKIYGEHIEYFDFSKSEINTSIFENCTFLDCSFEG } \\
\text { ASFVDVVFQNCNLSNSNFTDAYFERCQFIACKCVGVNMIDTIFKQTSMQRSNFQYSYFDKAKMTDIAFEDIDF } \\
\text { TEVSITEAKLKRFKAKNSHFIKNNFFKTMLTGVDFTKNELVAPTVSSPPIEFQGAKISMVQAADLIGLWGIIV } \\
\text { EQSGSGFMMGDWMSSFSTPVWISQAQGIRAGPGSSDKQEGEWPTGLRLSRIGGIH }\end{array}$ \\
\hline $\begin{array}{l}{[L=242]} \\
\text { (full-length } \\
\text { PENT) }\end{array}$ & $\begin{array}{l}\text { MSISNPRIPADLIMVDDFSSYAQGYLYEEIPITQIKIYGEHIEYFDFSKSEINTSIFENCTFLDCSFEG } \\
\text { ASFVDVVFQNCNLSNSNFTDAYFERCQFIACKCVGVNMIDTIFKQTSMQRSNFQYSYFDKAKMTDIAFEDIDF } \\
\text { TEVSITEAKLKRFKAKNSHFIKNNFFKTMLTGVDFTKNELVAPTVSSPPIEFQGAKISMVQAADLIGLWGIIV } \\
\text { EQSGSGWMSSFSTPVWISQAQGIRAGPGSSDKQEGEWPTGLRLSRIGGIH }\end{array}$ \\
\hline $\begin{array}{l}{[L=238]} \\
\text { (full-length } \\
\text { PENT) }\end{array}$ & $\begin{array}{l}\text { MSISNPRIPADLIMVDDFSSYAQGYLYEEIPITQIKIYGEHIEYFDFSKSEINTSIFENCTFLDCSFEG } \\
\text { ASFVDVVFQNCNLSNSNFTDAYFERCQFIACKCVGVNMIDTIFKQTSMQRSNFQYSYFDKAKMTDIAFEDIDF } \\
\text { TEVSITEAKLKRFKAKNSHFIKNNFFKTMLTGVDFTKNELVAPTVSSPPIEFQGAKISMVQAADLIGLWGIV } \\
\text { EQSGSGFSTPVWISQAQGIRAGPGSSDKQEGEWPTGLRLSRIGGIH }\end{array}$ \\
\hline
\end{tabular}




\begin{tabular}{|c|c|}
\hline$[L=216]$ & $\begin{array}{l}\text { MANRSFIYEPFQIPSGSMMPTLNSTDFILVEKFAYGIKDPIYQKTLIETGHPKRGDIVVFKYPEDPKLDYIKR } \\
\text { AVGLPGDKVTYDPVSKELTIQPGCSSGQACENALPVTYSNVEPSDFVQTFSRRNGGEATSGFFEVPKQETKEN } \\
\text { GIRLSETSGSGSMSISNPRIPADLIMVDDFSSYAQGYLYEEIPITQIKIYGEHIEYFDFSKSEINTSIFENCT } \\
\text { FLDCSFEGASFVDVVFQNCNLSNSNFTDAYFERCQFIACKCVGVNMIDTIFKQTSMQRSNFQYSYFDKAKMTD } \\
\text { IAFEDIDFTEVSITEAKLKRFKAKNSHFIKNNFFKTMLTGVDFTKNELVAPTVSSPPIEFQSGSGFSTPVWIS } \\
\text { QAQGIRAGPGSSDKQEGEWPTGLRLSRIGGIH }\end{array}$ \\
\hline$[L=205]$ & $\begin{array}{l}\text { [ Lep } 154 \text { ] GSGSMS ISNPRIPADLIMVDDFSSYAQGYLYEEIPITQIKIYGEHIEYFDFSKSEINTSIFENCT } \\
\text { FLDCSFEGASFVDVVFQNCNLSNSNFTDAYFERCQFIACKCVGVNMIDTIFKQTSMQRSNFQYSYFDKAKMTD } \\
\text { IAFEDIDFTEVSITEAKLKRFKAKNSHFIKNNFFKTMLTGVDFTKNELVASGSGFSTPVWISQAQGIRAGPGS } \\
\text { SDKQEGEWPTGLRLSRIGGIH }\end{array}$ \\
\hline$[L=194]$ & $\begin{array}{l}\text { [ Lep } 154 \text { ] GSGSMS ISNPRIPADLIMVDDFSSYAQGYLYEEIPITQIKIYGEHIEYFDFSKSEINTSIFENCT } \\
\text { FLDCSFEGASFVDVVFQNCNLSNSNFTDAYFERCQFIACKCVGVNMIDTIFKQTSMQRSNFQYSYFDKAKMTD } \\
\text { IAFEDIDFTEVSITEAKLKRFKAKNSHFIKNNFFKTMLTSGSGFSTPVWISQAQGIRAGPGSSDKQEGEWPTG } \\
\text { LRLSRIGGIH }\end{array}$ \\
\hline$[L=183]$ & $\begin{array}{l}\text { [ Lep } 154 \text { ] GSGSMS ISNPRIPADLIMVDDFSSYAQGYLYEEIPITQIKIYGEHIEYFDFSKSEINTSIFENCT } \\
\text { FLDCSFEGASFVDVVFQNCNLSNSNFTDAYFERCQFIACKCVGVNMIDTIFKQTSMQRSNFQYSYFDKAKMTD } \\
\text { IAFEDIDFTEVSITEAKLKRFKAKNSHFSGSGFSTPVWISQAQGIRAGPGSSDKQEGEWPTGLRLSRIGGIH }\end{array}$ \\
\hline$[L=172]$ & $\begin{array}{l}\text { [Lep } 154 \text { ] GSGSMS ISNPRIPADLIMVDDFSSYAQGYLYEEIPITQIKIYGEHIEYFDFSKSEINTSIFENCT } \\
\text { FLDCSFEGASFVDVVFQNCNLSNSNFTDAYFERCQFIACKCVGVNMIDTIFKQTSMQRSNFQYSYFDKAKMTD } \\
\text { IAFEDIDFTEVSITEAKSGSGFSTPVWISQAQGIRAGPGSSDKQEGEWPTGLRLSRIGGIH }\end{array}$ \\
\hline$[L=169]$ & $\begin{array}{l}\text { [Lep } 154 \text { ] GSGSMSISNPRIPADLIMVDDFSSYAQGYLYEEIPITQIKIYGEHIEYFDFSKSEINTSIFENCT } \\
\text { FLDCSFEGASFVDVVFQNCNLSNSNFTDAYFERCQFIACKCVGVNMIDTIFKQTSMQRSNFQYSYFDKAKMTD } \\
\text { IAFEDIDFTEVSITSGSGFSTPVWISQAQGIRAGPGSSDKQEGEWPTGLRLSRIGGIH }\end{array}$ \\
\hline$[L=164]$ & $\begin{array}{l}\text { [Lep } 154 \text { ] GSGSMS ISNPRIPADLIMVDDFSSYAQGYLYEEIPITQIKIYGEHIEYFDFSKSEINTSIFENCT } \\
\text { FLDCSFEGASFVDVVFQNCNLSNSNFTDAYFERCQFIACKCVGVNMIDTIFKQTSMQRSNFQYSYFDKAKMTD } \\
\text { IAFEDIDFTSGSGFSTPVWISQAQGIRAGPGSSDKQEGEWPTGLRLSRIGGIH }\end{array}$ \\
\hline$[L=161]$ & $\begin{array}{l}\text { [Lep } 154 \text { ] GSGSMS ISNPRIPADLIMVDDFSSYAQGYLYEEIPITQIKIYGEHIEYFDFSKSEINTSIFENCT } \\
\text { FLDCSFEGASFVDVVFQNCNLSNSNFTDAYFERCQFIACKCVGVNMIDTIFKQTSMQRSNFQYSYFDKAKMTD } \\
\text { IAFEDISGSGFSTPVWISQAQGIRAGPGSSDKQEGEWPTGLRLSRIGGIH }\end{array}$ \\
\hline$[L=158]$ & $\begin{array}{l}\text { [Lep } 154 \text { ] GSGSMS ISNPRIPADLIMVDDFSSYAQGYLYEEIPITQIKIYGEHIEYFDFSKSEINTSIFENCT } \\
\text { FLDCSFEGASFVDVVFQNCNLSNSNFTDAYFERCQFIACKCVGVNMIDTIFKQTSMQRSNFQYSYFDKAKMTD } \\
\text { IAFSGSGFSTPVWISQAQGIRAGPGSSDKQEGEWPTGLRLSRIGGIH }\end{array}$ \\
\hline$[L=154]$ & $\begin{array}{l}\text { [ Lep } 154 \text { ] GSGSMSISNPRIPADLIMVDDFSSYAQGYLYEEIPITQIKIYGEHIEYFDFSKSEINTSIFENCT } \\
\text { FLDCSFEGASFVDVVFQNCNLSNSNFTDAYFERCQFIACKCVGVNMIDTIFKQTSMQRSNFQYSYFDKAKMTS } \\
\text { GSGFSTPVWISQAQGIRAGPGSSDKQEGEWPTGLRLSRIGGIH }\end{array}$ \\
\hline$[L=150]$ & $\begin{array}{l}\text { [Lep } 154 \text { ] GSGSMS ISNPRIPADLIMVDDFSSYAQGYLYEEIPITQIKIYGEHIEYFDFSKSEINTSIFENCT } \\
\text { FLDCSFEGASFVDVVFQNCNLSNSNFTDAYFERCQFIACKCVGVNMIDTIFKQTSMQRSNFQYSYFDKSGSGF } \\
\text { STPVWISQAQGIRAGPGSSDKQEGEWPTGLRLSRIGGIH }\end{array}$ \\
\hline$[L=147]$ & $\begin{array}{l}\text { [Lep } 154 \text { ] GSGSMSISNPRIPADLIMVDDFSSYAQGYLYEEIPITQIKIYGEHIEYFDFSKSEINTSIFENCT } \\
\text { FLDCSFEGASFVDVVFQNCNLSNSNFTDAYFERCQFIACKCVGVNMIDTIFKQTSMQRSNFQYSYSGSGFSTP } \\
\text { VWISQAQGIRAGPGSSDKQEGEWPTGLRLSRIGGIH }\end{array}$ \\
\hline$[L=143]$ & $\begin{array}{l}\text { [Lep } 154 \text { ] GSGSMS ISNPRIPADLIMVDDFSSYAQGYLYEEIPITQIKIYGEHIEYFDFSKSEINTSIFENCT } \\
\text { FLDCSFEGASFVDVVFQNCNLSNSNFTDAYFERCQFIACKCVGVNMIDTIFKQTSMQRSNFSGSGFSTPVWIS } \\
\text { QAQGIRAGPGSSDKQEGEWPTGLRLSRIGGIH }\end{array}$ \\
\hline$[L=139]$ & $\begin{array}{l}\text { [ Lep } 154 \text { ] GSGSMS ISNPRIPADLIMVDDFSSYAQGYLYEEIPITQIKIYGEHIEYFDFSKSEINTSIFENCT } \\
\text { FLDCSFEGASFVDVVFQNCNLSNSNFTDAYFERCQFIACKCVGVNMIDTIFKQTSMQSGSGFSTPVWISQAQG } \\
\text { IRAGPGSSDKQEGEWPTGLRLSRIGGIH }\end{array}$ \\
\hline
\end{tabular}




\begin{tabular}{|c|c|}
\hline$[L=130]$ & $\begin{array}{l}\text { [Lep } 154 \text { ] GSGSMSISNPRIPADLIMVDDFSSYAQGYLYEEIPITQIKIYGEHIEYFDFSKSEINTSIFENCT } \\
\text { FLDCSFEGASFVDVVFQNCNLSNSNFTDAYFERCQFIACKCVGVNMIDSGSGFSTPVWISQAQGIRAGPGSSD } \\
\text { KQEGEWPTGLRLSRIGGIH }\end{array}$ \\
\hline$[L=121]$ & $\begin{array}{l}\text { [ Lep } 154 \text { ] GSGSMSISNPRIPADLIMVDDFSSYAQGYLYEEIPITQIKIYGEHIEYFDFSKSEINTSIFENCT } \\
\text { FLDCSFEGASFVDVVFQNCNLSNSNFTDAYFERCQFIACSGSGFSTPVWISQAQGIRAGPGSSDKQEGEWPTG } \\
\text { LRLSRIGGIH }\end{array}$ \\
\hline$[L=117]$ & $\begin{array}{l}\text { [Lep } 154 \text { ] GSGSMSISNPRIPADLIMVDDFSSYAQGYLYEEIPITQIKIYGEHIEYFDFSKSEINTSIFENCT } \\
\text { FLDCSFEGASFVDVVFQNCNLSNSNFTDAYFERCQSGSGFSTPVWISQAQGIRAGPGSSDKQEGEWPTGLRLS } \\
\text { RIGGIH }\end{array}$ \\
\hline$[L=114]$ & $\begin{array}{l}\text { [Lep } 154 \text { ] GSGSMSISNPRIPADLIMVDDFSSYAQGYLYEEIPITQIKIYGEHIEYFDFSKSEINTSIFENCT } \\
\text { FLDCSFEGASFVDVVFQNCNLSNSNFTDAYFESGSGFSTPVWISQAQGIRAGPGSSDKQEGEWPTGLRLSRIG } \\
\text { GIH }\end{array}$ \\
\hline$[L=110]$ & $\begin{array}{l}\text { [Lep } 154 \text { ] GSGSMSISNPRIPADLIMVDDFSSYAQGYLYEEIPITQIKIYGEHIEYFDFSKSEINTSIFENCT } \\
\text { FLDCSFEGASFVDVVFQNCNLSNSNFTDSGSGFSTPVWISQAQGIRAGPGSSDKQEGEWPTGLRLSRIGGIH }\end{array}$ \\
\hline$[L=107]$ & $\begin{array}{l}\text { [ Lep } 154 \text { ] GSGSMSISNPRIPADLIMVDDFSSYAQGYLYEEIPITQIKIYGEHIEYFDFSKSEINTSIFENCT } \\
\text { FLDCSFEGASFVDVVFQNCNLSNSNSGSGFSTPVWISQAQGIRAGPGSSDKQEGEWPTGLRLSRIGGIH }\end{array}$ \\
\hline$[L=100]$ & $\begin{array}{l}\text { [Lep } 154 \text { ] GSGSMSISNPRIPADLIMVDDFSSYAQGYLYEEIPITQIKIYGEHIEYFDFSKSEINTSIFENCT } \\
\text { FLDCSFEGASFVDVVFQNSGSGFSTPVWISQAQGIRAGPGSSDKQEGEWPTGLRLSRIGGIH }\end{array}$ \\
\hline$[L=93]$ & $\begin{array}{l}\text { [ Lep } 154 \text { ] GSGSMSISNPRIPADLIMVDDFSSYAQGYLYEEIPITQIKIYGEHIEYFDFSKSEINTSIFENCT } \\
\text { FLDCSFEGASFSGSGFSTPVWISQAQGIRAGPGSSDKQEGEWPTGLRLSRIGGIH }\end{array}$ \\
\hline$[L=86]$ & $\begin{array}{l}\text { [Lep } 154 \text { ] GSGSMSISNPRIPADLIMVDDFSSYAQGYLYEEIPITQIKIYGEHIEYFDFSKSEINTSIFENCT } \\
\text { FLDCSGSGFSTPVWISQAQGIRAGPGSSDKQEGEWPTGLRLSRIGGIH }\end{array}$ \\
\hline$[L=79]$ & $\begin{array}{l}\text { [ Lep } 154 \text { ] GSGSMSISNPRIPADLIMVDDFSSYAQGYLYEEIPITQIKIYGEHIEYFDFSKSEINTSIFESGS } \\
\text { GFSTPVWISQAQGIRAGPGSSDKQEGEWPTGLRLSRIGGIH }\end{array}$ \\
\hline$[L=75]$ & $\begin{array}{l}\text { [ Lep } 154 \text { ] GSGSMSISNPRIPADLIMVDDFSSYAQGYLYEEIPITQIKIYGEHIEYFDFSKSEINTSGSGFST } \\
\text { PVWISQAQGIRAGPGSSDKQEGEWPTGLRLSRIGGIH }\end{array}$ \\
\hline$[L=72]$ & $\begin{array}{l}\text { [ Lep } 154 \text { ] GSGSMSISNPRIPADLIMVDDFSSYAQGYLYEEIPITQIKIYGEHIEYFDFSKSESGSGFSTPVW } \\
\text { ISQAQGIRAGPGSSDKQEGEWPTGLRLSRIGGIH }\end{array}$ \\
\hline$[L=68]$ & $\begin{array}{l}\text { [Lep } 154 \text { ] GSGSMSISNPRIPADLIMVDDFSSYAQGYLYEEIPITQIKIYGEHIEYFDFSGSGFSTPVWISQA } \\
\text { QGIRAGPGSSDKQEGEWPTGLRLSRIGGIH }\end{array}$ \\
\hline$[L=65]$ & $\begin{array}{l}\text { [ Lep } 154 \text { ] GSGSMSISNPRIPADLIMVDDFSSYAQGYLYEEIPITQIKIYGEHIEYSGSGFSTPVWISQAQGI } \\
\text { RAGPGSSDKQEGEWPTGLRLSRIGGIH }\end{array}$ \\
\hline$[L=58]$ & $\begin{array}{l}\text { [Lep } 154 \text { ] GSGSMSISNPRIPADLIMVDDFSSYAQGYLYEEIPITQIKISGSGFSTPVWISQAQGIRAGPGSS } \\
\text { DKQEGEWPTGLRLSRIGGIH }\end{array}$ \\
\hline$[L=51]$ & $\begin{array}{l}\text { [ Lep } 154 \text { ] GSGSMSISNPRIPADLIMVDDFSSYAQGYLYEEISGSGFSTPVWISQAQGIRAGPGSSDKQEGEW } \\
\text { PTGLRLSRIGGIH }\end{array}$ \\
\hline
\end{tabular}

